\title{
Total cholesterol and C-reactive Protein (CRP) levels as prognostic markers for urosepsis by Soetojo Soetojo
}

Submission date: 06-Aug-2019 06:49PM (UTC+0800)

Submission ID: 1158058425

File name: tive_Protein_CRP_levels_as_prognostic_markers_for_urosepsis.pdf (1.63M)

Word count: 3426

Character count: 16756 


\title{
Total Cholesterol and C-reactive Protein (CRP) Levels as Prognostic Markers for Urosepsis
}

\author{
Septa Surya Wahyudi ${ }^{1}$, Budiono $^{1}$, Tarmono ${ }^{1}$, Soetojo ${ }^{1}$, Doddy M. Soebadi', Sunaryo Hardjowijoto ${ }^{1}$ \\ 'Department of Urology, Faculty of Medicine, Airlangga University, Surabaya 60115 Indonesia
}

\begin{abstract}
This study was aimed to determine and compared the total cholesterol and C-reactive protein (CRP) levels as a prognosis in urosepsis patients treated at the RSUD. Dr. Soetomo Hospital. There were 30 patients involved in this study and was assigned to the test for total cholesterol and CRP level at the day of admission, three days later, and on the last day (14th days) of sepsis or on the day of the death. The variables were tested using the Spearman's rho test with software SPSS 20. This study found 15 patients who were in septic condition, 14 patients had severe sepsis and one patient had septic shock. There were statistically significant between total cholesterol and CRP levels in determining the outcome of urosepsis patient. The coefficient correlation of total cholesterol was better than CRP. The low total cholesterol levels and high CRP levels can be used as predictors of worsening urosepsisprognosis. Total cholesterol levels showed better performance than CRP as a prognostic marker for urosepsis.
\end{abstract}

Keywords: Cholesterol level, C-reactive Protein (CRP), Prognostic Marker, Urosepsis

\section{Introduction}

Urosepsis was a sepsis that originates from urinary tract infections with symptoms of SIRS ${ }^{1}$.Sepsis that was not adequately treated can fall under severe sepsis with MODS and even septic shock ${ }^{2,3}$. The sepsis can change body hemodynamics, hematology and metabolism $\therefore$ body by involving immune system responses and many organ systems ${ }^{1,4}$. In severe sepsis and septic shock there can be circulatory distress syndrome at the micro and mitochondrial levels. Hemodynamic and severe circulation disorders can cause disruption of oxygen transport and cell respiration which can cause failure of many organs. Mitochondrial dysfunction plays an important role in sepsis where the rate of mitochondrial respiration dysfunction was related to the patient's outcome. Mitochondrial failure associated with sepsis role in respiratory distress, especially in areas of hypoxia and can cause distress networks that can progress to organ dysfunction ${ }^{5,6}$.

\section{Corresponding author:}

Soetojo

E-mail: soetojo@fk.unair.ac.id
There were several clinical and laboratory variables that can be used as markers to determine and assess the severity of sepsis and determine its prognosis. One of them was total cholesterol. Cholesterol involvement in this sepsis condition allows cholesterol to be used as a biomarker for urosepsis. Decrease in total cholesterol in sepsis occurs from the first time bacterial toxins enter the patient's blood (host) and will further reduce the decrease in patients with severe sepsis accompanied by $\operatorname{MODS}^{7.8}$

The reduction in total cholesterol was basically a decrease in HDL cholesterol, LDL cholesterol and VLDL cholesterol. The total cholesterol was decrease due to multi factorial factors including increased cholesterol usage in the sepsis process, decreased synthesis and changes in metabolism ${ }^{9,10,11}$. The use of cholesterol in sepsis occurs since bacterial toxins enter the patient's body. Both endotoxins (lipopolysaccharides) from gram-negative bacteria and lipoteichoic acid (LTA) from gram-positive bacteria will bond between lipopolysaccharide (LPS) and cholesterol (lipoprotein) known as lipopolysaccharide binding protein $(\mathrm{LBP})^{12,13}$. This cholesterol bond with lipopolysaccharide (LBP) aims to neutralize germ toxins and reduce cellular response caused by gram-negative and gram-positive 
bacteria $^{10,14}$. In addition to reduce the cellular response of the host to endotoxin, LBP also aims to present endotoxin monomers (LPS) in membrane bound CD 14 in monocytes, neutrophils and macrophages ${ }^{15}{ }^{16}$.Thus, the invasion of germs can be prevented and overcome ${ }^{4,17}$. Decreased cholesterol synthesis in liver also occurs in sepsis, thiswas related to an increase in cytokine mediators in the form of TNF $\alpha, \mathrm{IL}-1$ and interleukin $6^{10}$. Decreased lipoprotein (cholesterol) was seen after liver cells were exposed to TNF $\alpha$, IL-1 and IL-6. This study was aimed to determine and compared the total cholesterol and C-reactive protein (CRP) levels as a prognosis in urosepsis patients treated at the RSUD. Dr. Soetomo Hospital.

\section{Methodology}

This study was a prospective study of the type of diagnostic test which highlight on the comparison of total cholesterol levels and C-reactive protein (CRP) พิ in assessing urosepsisprognosis through observational analytic research designs. The study sample focused on 递 the patients who were diagnosed with urosepsis (sepsis c caused by urinary tract infection). and treated at the RSUD. Dr. Soetomo Hospital. The sampleswas calculated based on the formula of the sample size for correlative analytic test research. All respondentswere required to sign an approval sheet following the research. On the first day, the respondentswere classified based on the results of assessment for clinical severity, total cholesterol, CRP, MAP, blood leukocytes, urinalysis, urine culture and blood culture, BGA (blood gas analysis), SGOT, SGPT, BUN, and serum creatinine level. On the third day the patients were reassessed for their clinical severity, total cholesterol, and CRP. Patients were continuing follow this study until the last day of the patient's death, recovery or a maximum of 14 days of treatment. The correlation test was performed between total cholesterol and CRP results on the outcome / prognosis of the urosepsis patient.

The results of the study werecollected and processed with the SPSS program. The statistical test used was a bivariate correlation test between total cholesterol and
CRP against the prognosis (outcome) of patients with the Spearman's rho test. The correlation coefficients of each variable was determined to compare the correlation strength between CRP and blood cholesterol against the prognosis (outcome) of patients with urosepsis.

\section{Result and Discussion}

Table 1 showed the CRP score and total cholesterol based on outcome. The average results of the first day CRP examination in patients was $177.18 \pm 107.37 \mathrm{mg} / \mathrm{L}$, worsening $146.74 \pm 62.82 \mathrm{mg} / \mathrm{L}$, whereas in patients with improved outcome showed low average CRP score which was $88.10 \pm 74.41 \mathrm{mg} / \mathrm{L}$. The mean CRP values on the third and last day of patients with clinically improved decreased from $56.28 \pm 50.15 \mathrm{mg} / \mathrm{L}$ to 31.58 $\pm 37.37 \mathrm{mg} / \mathrm{L}$. The mean CRP of patients died on the third day was $127.10 \pm 106.28 \mathrm{mg} / \mathrm{L}$ and on the last day was $141.88 \pm 105.61 \mathrm{mg} / \mathrm{L}$. The difference $(\Delta)$ of CRP between last day and first day showed positive value in the patient with outcome deteriorated which was 38.76 $\pm 59.02 \mathrm{mg} / \mathrm{L}$, while the negative value in the patient improved and died were $-56.52 \pm 70.20 \mathrm{mg} / \mathrm{L}$ and -35.3 $\pm 97.53 \mathrm{mg} / \mathrm{L}$ respectively.

Examination of total cholesterol based on outcome at the end of the study showed lowest average total cholesterol examination results on the first day in patients with death outcomes that was equal to $63.25 \pm$ $14.15 \mathrm{mg} / \mathrm{dL}$ and then increased follow by worsening patients which was $101.38 \pm 20.51 \mathrm{mg} / \mathrm{dL}$ and improved patients which was $119.5 \pm 17.81 \mathrm{mg} / \mathrm{dL}$.Meanwhile, patients with outcome worsening and dying clearly seen total cholesterol values continued to decline. In patients worsening the total cholesterol value for the third day was $93.62 \pm 10.68 \mathrm{mg} / \mathrm{dL}$ and the last day was 82.25 $\pm 10.9 \mathrm{mg} / \mathrm{dL}$. In patients who died in third day, total cholesterol value was $56.0 \pm 6.98 \mathrm{mg} / \mathrm{dL}$ and the last day was $51.0 \pm 6.16 \mathrm{mg} / \mathrm{dL}$. The difference $(\Delta)$ of cholesterol between the last day and first day showed positive mean value which was $35.3 \pm 21.46 \mathrm{mg} / \mathrm{dL}$ for patients improved. While, negative mean values in patients who worsened and died were $-19.13 \pm 18.45 \mathrm{mg} / \mathrm{dL}$ and $-12.25 \pm 11.59 \mathrm{mg} / \mathrm{dL}$. 
Table 1. CRP levels and total cholesterol based on outcome

\begin{tabular}{|c|c|c|c|c|c|c|c|c|c|}
\hline \multirow{2}{*}{ Criteria } & \multicolumn{3}{|c|}{ Improved } & \multicolumn{3}{|c|}{ Worsening } & \multicolumn{3}{|c|}{ Died } \\
\hline & n & Mean & SD & $\mathbf{n}$ & Mean & SD & $\mathbf{n}$ & Mean & SD \\
\hline $1^{\text {st }} \mathrm{CRP}(\mathrm{mg} / \mathrm{L})$ & 18 & 88.10 & 74.41 & 8 & 146.74 & 62.82 & 4 & 177.18 & 107.37 \\
\hline $3^{\text {rd }} \mathrm{CRP}(\mathrm{mg} / \mathrm{L})$ & 18 & 56.28 & 50.15 & 8 & 148.88 & 63.15 & 4 & 127.10 & 106.28 \\
\hline $14^{\text {th }} \mathrm{CRP}(\mathrm{mg} / \mathrm{L})$ & 18 & 31.58 & 37.37 & 8 & 185.50 & 88.71 & 4 & 141.88 & 105.61 \\
\hline$\Delta\left(14^{\text {th }} \mathrm{CRP}-1^{\text {st }} \mathrm{CRP}\right)(\mathrm{mg} / \mathrm{L})$ & 18 & -56.52 & 70.20 & 8 & 38.76 & 59.02 & 4 & -35.3 & 97.53 \\
\hline $1^{\text {st }} \mathrm{Chol}(\mathrm{mg} / \mathrm{dL})$ & 18 & 119.50 & 17.81 & 8 & 101.38 & 20.51 & 4 & 63.25 & 14.15 \\
\hline $3^{\text {rd }} \mathrm{Chol}(\mathrm{mg} / \mathrm{dL})$ & 18 & 128.61 & 23.61 & 8 & 93.62 & 10.68 & 4 & 56.00 & 6.98 \\
\hline $14^{\text {th }} \mathrm{Chol}(\mathrm{mg} / \mathrm{dL})$ & 18 & 154.83 & 25.71 & 8 & 82.25 & 10.9 & 4 & 51 & 6.16 \\
\hline$\Delta\left(14^{\text {th }} \mathrm{Chol}-1^{\text {st }} \mathrm{Chol}\right)(\mathrm{mg} / \mathrm{dL})$ & 18 & 35.3 & 21.46 & 8 & -19.13 & 18.45 & 4 & -12.25 & 11.59 \\
\hline
\end{tabular}

The correlation test was performed using Spearman's rho method in order to determine the significance and के strength of correlation (correlation coefficient). Correlation test was performed between first day CRP, third day CRP,

last day CRP, delta $(\Delta)$ CRP (14th CRP - 1st CRP), total cholesterol of first day, third day, last day, and delta $(\Delta)$ total cholesterol $(\Delta$ 14th Chol -1st Chol)) against the outcome of patients with urosepsis. CRP and total cholesterol statistical tests were conducted in all study samples. All study samples were observed and assessed on the outcome $\stackrel{\otimes}{\Phi}$ or the condition of the patient until the last day the patient was declared cured or died.

Table 2. Results of the Correlation Test of CRP levels with the outcome using the Spearman's rho formula $(\mathrm{n}=$ all samples)

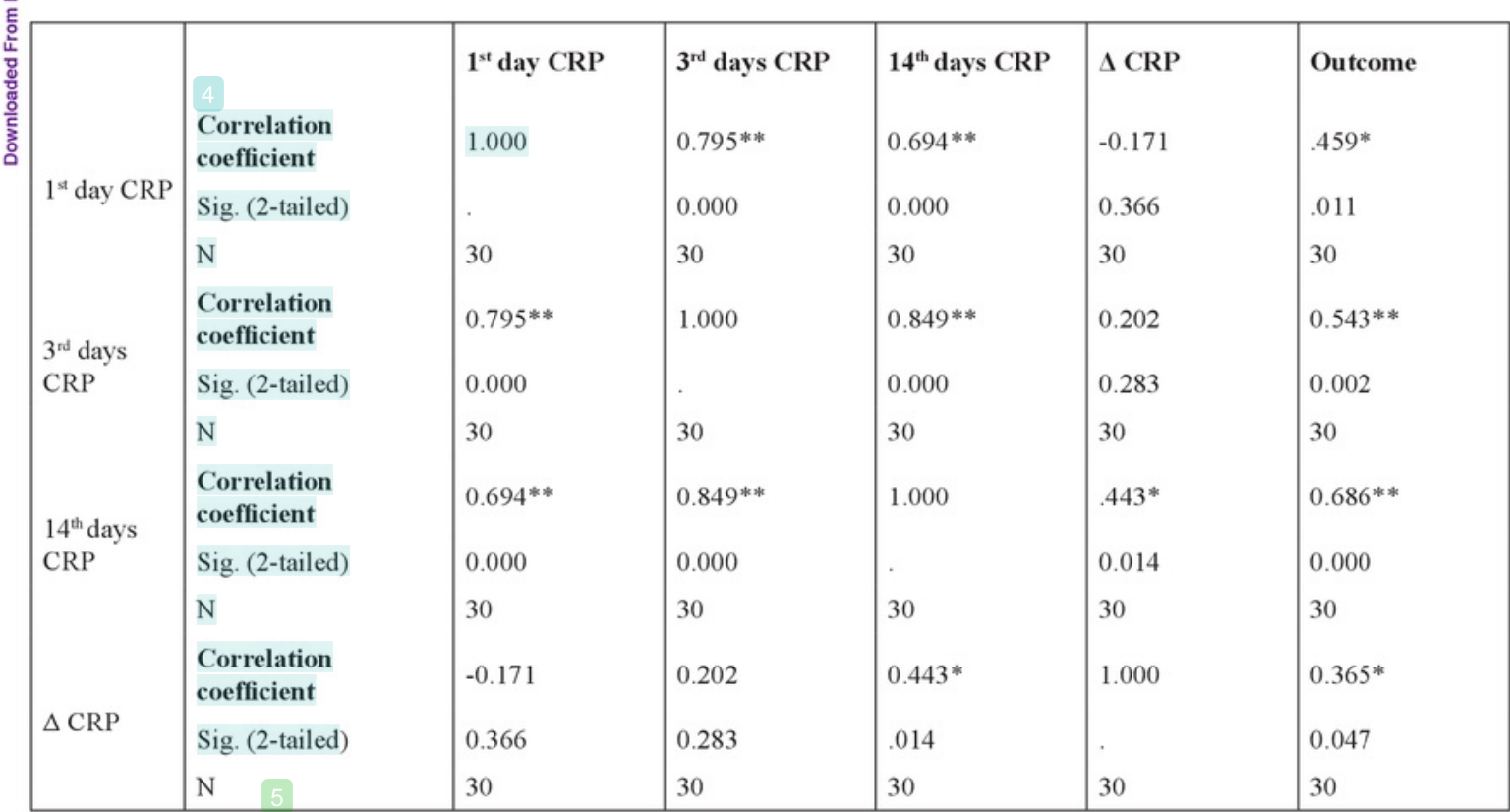

* Correlation was significant at the 0.05 level (2-tailed)

** Correlation was significant at the 0.01 level (2-tailed) 
Based on Table 3, the value of the correlation test of CRP levels on outcome in patients with urosepsis using the Spearman's rho formula was shown in Table 3. Based on statistical tests it was found that CRP levels on the first, third, fourteen days, and delta CRP (day 14 minus the first day) in patients with urosepsis showed a significant correlation $(\mathrm{p}<0.05)$ to the outcome with a significance value of $0.011,0.002,0,000$ and 0.047 respectively and the correlation coefficients (r) were $0.459,0,543,0.686$, and 0.365 respectively.

Table 3. Results of Correlation Test of Total Cholesterol Level with outcome using Spearman's rho formula ( $n=$ all samples)

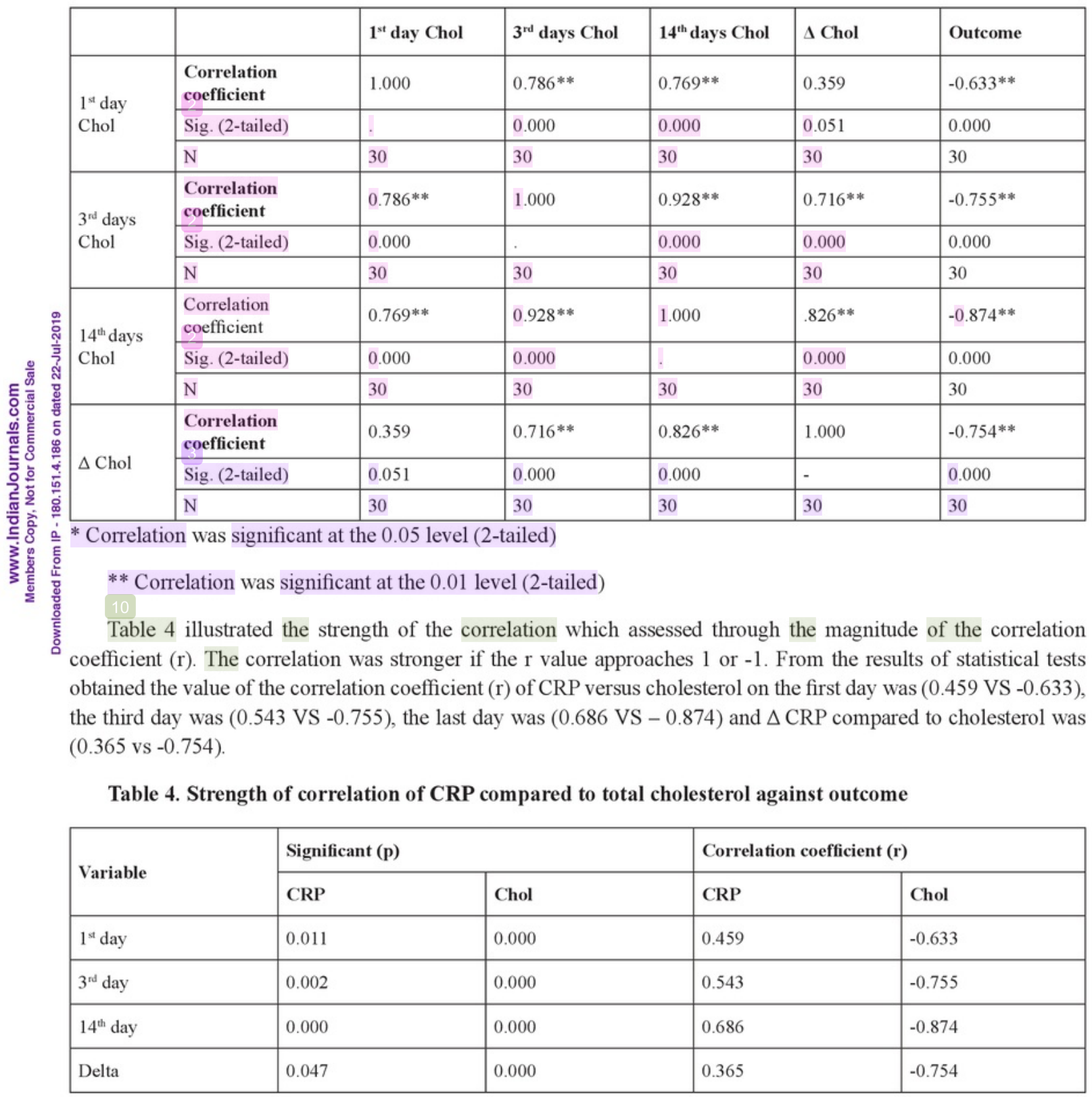




\section{Discussion}

Increased CRP levels require a minimum of 12 18 hours and CRP increased slowly during sepsis and reaches peak levels in $36-50$ hours. The concentration will drop rapidly with a half-life of 19 hours if the stimulus was removed. This causes CRP to be independent and only affected by therapy and actions to eliminate the inflammatory process. In this study, 4 patients died with varying initial CRP levels of $53.0 \mathrm{mg} / \mathrm{L}, 156.0 \mathrm{mg} / \mathrm{L}$, $186 \mathrm{mg} / \mathrm{L}$ and $313.7 \mathrm{mg} / \mathrm{L}$. The high level of CRP can be a description of the number of organ systems that have failed their function ${ }^{18}$.

In this study, the first day CRP levels in patients with improved outcomes had the lowest average compared to the first day CRP levels in patients with worsening and dying outcomes, which was $88.10 \pm 74.41 \mathrm{mg} / \mathrm{L}$ compared to $146.74 \pm 62.82 \mathrm{mg} / \mathrm{L}$ and $177.18 \pm 107.37$ o $\mathrm{mg} / \mathrm{L}$. On the third and final day examination, a very จิ clear pattern was seen that in patients with improved outcomes there was a lower CRP level of $56.28 \pm 50.15$ 善 $\mathrm{mg} / \mathrm{L}$ and $31.58 \pm 37.37 \mathrm{mg} / \mathrm{L}$. Whereas the worsening 5 of patients continued to increase, $148.88 \pm 63.15 \mathrm{mg} / \mathrm{L}$ on the third day and $185.50 \pm 88.71 \mathrm{mg} / \mathrm{L}$ on the last day. In patients with death outcomes, the mean on third day CRP level was $127.10 \pm 106.28 \mathrm{mg} / \mathrm{L}$ and on the last day it increased to $141.88 \pm 105.61 \mathrm{mg} / \mathrm{L}$. The results of the correlation test of CRP levels with the outcome obtained significant values $(\mathrm{p}<0.05)$ on the examination for the first, third, and last days were $0.459,0,543$, and 0.686 respectively. These results reflect that low CRP levels were associated with a good prognosis, whereas high CRP levels were associated with a poor prognosis even to death both on the first day, third day and last day examination.

This study was determined that total cholesterol and CRP concentration can be used as predictors of outcome and prognosis of urosepsis. Serial total cholesterol and CRP measurement (periodically) will be more helpful in identifying the patient's condition so that it can provide additional information to increase the aggressiveness of the action to be given. From the results of data analysis in this study it can also be determined that the total cholesterol level compared to CRP showed a higher correlation with the outcome of patients with urosepsis. So that the measurement of total cholesterol levels in patients with urosepsis was better in predicting outcome or prognosis when compared with CRP levels.

\section{Conclusion}

In conclusions, total cholesterol levels can be used as a marker of prognosis (improved / worsened / died) in urosepsis patients both on the first, third, and last day examination with a significant correlation $(\mathrm{p}<0.05)$. The lower the total cholesterol level the worse the prognosis of the patient and vice versa.CRP levels can be used as a marker of prognosis (improved / worsened / died) in urosepsis patients both on the first, third, and last day examination with a significant correlation $(\mathrm{p}<0.05)$. The higher the CRP level the worse the prognosis of the patient and vice versa. Plasma total cholesterol levels showed a greater correlation coefficient than CRP levels on patient outcomes with urosepsis both on the first day examination (- 0.633 vs. 0.459$)$, third ( -0.755 vs 0.543$)$, and the last day (-0.874 vs 0.686$)$. So that total plasma cholesterol levels can be used as a better prognosis indicator than CRP levels.

Ethical Clearance: Taken from the committee

\section{Source of Funding: Nil}

\section{Conflict of Interest: Nil}

\section{References}

1. F.M. Wagenlehner, W. Weidner, K.G. Naber. "Optimal management of urosepsis from the urological perspective". International Journal of Antimicrobial Agents. 2007;30(5):390-397.

2. R.C. Bone et al. "Definitions for sepsis and organ failure and guidelines for the use of innovative therapies in sepsis". Chest. 1992;101(6):16441655.

3. N. Sen, A. Matthias, J. P. Raj. "Role of critical care in urological sepsis". Indian Journal of Urology. 2006;22(2): 105-112.

4. R.S. Hotchkiss, I.E. Karl. "The pathophysiology and treatment of sepsis". The New England Journal of Medicine. 2003;348:138-150.

5. P.E. Spronk, D.F. Zandstra, C. Ince. "Benchto-bedside review: sepsis is a disease of the microcirculation". Critical Care. 2004;8(6):462468.

6. C. Ince."The microcirculation is the motor of sepsis". Critical Care. 2005;9(4):13-19.

7. C. Chiarla et al. "Severe hypocholesterolemia 
in surgical patients, sepsis, and critical illness". Journal of Critical Care. 2010;25(2).

8. P. Vyroubal et al. "Hypocholesterolemia in clinically serious conditions-review". Biomedical Papers of the Medical Faculty of the University Palacky, Olomouc, Czechoslovkia. 2008;152(2):181-189.

9. I, Giovannini, G. Boldrini, C. Chiarla, F. Giuliante, M. Vellone, G. Nuzzo. "Pathophysiologic correlates of hypocholesterolemia in critically ill surgical patients". Intensive Care Medicine. 1999;25(7):748-751.

10. B.R. Gordon et al. "Relationship of hypolipidemia to cytokine concentrations and outcomes in critically ill surgical patients". Critical Care Medicine. 2001;29(8):1563-1568.

11. L. Siracusana, V. Girasole. "The role of altered lipid metabolism in septic myocardial ণั dysfunction" Intect Open Science. 2003.

12. J.H.M. Levels, P.R. Abraham, A.V.D. Ende, S.J.H. van Deventer."Distribution and kinetics of lipoprotein -bound endotoxin". Infect and Immunity. 2001;69(5):2821-2828.

13. J.H.M. Levels, P.R. Abraham, A.V.D. Ende, S.J.H. van Deventer."Distribution and kinetics of lipoprotein -bound lipoprotein acid". Infect and Immunity. 2003;71(6):3280-3284.

14. D. Pajkrt et al. "Antinflammatory effects of reconstituted high-density lipoprotein during human endotoxemia". The Journal of Experimental Medicine. 1996;184(5):1601-1608.

15. C.J. Vesy, R.L. Kitchens, G. Wolfbauer, J.J. Albers , R.S. Munford. 'Lipopolysaccharidebinding protein and phospholipid transfer protein release lipopolysaccharides from gram-negative bacterial membranes". infection and Immunity. 2000;68(5):2410-2417.

16. M. M. Wurfel, S.T. Kunitake, H. Lichenstein, J.P. Kane, S.D. Wright. "Lipopolysaccharide (LPS)-binding Protein Is Carried on Lipoprotein and Acts as a cofactor in the Neutralization of LPS". The Journal of Experimental Medicine. 1994;180(3): 1025-1035.

17. S.S. Dhillon et al. "Neutrophils, nitric oxide and microvascular permeability in severe sepsis". Chest. 2005;128(3): 1706-1712.

18. S.M. Lobo et al. "C-Reactive Protein Levels Correlate With Mortality and Organ Failure in Critically Ill Patients". Chest. 2003;123(6):2043-2049. 


\section{Total cholesterol and C-reactive Protein (CRP) levels as}

prognostic markers for urosepsis

ORIGINALITY REPORT

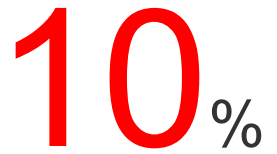

SIMILARITY INDEX
$9 \%$

INTERNET SOURCES
$6 \%$

PUBLICATIONS
$0 \%$

STUDENT PAPERS

\section{PRIMARY SOURCES}

1 uad.portalgaruda.org

Internet Source

2 article.sciencepublishinggroup.com

Internet Source

3 repository.tudelft.nl

Internet Source

$4 \quad$ www.sociology.cass.cn

Internet Source

5 docshare.tips

Internet Source

6 "Abstracts cont.", Clinical Microbiology and Infection, 2004

Dzul Istiqomah Hasyim. "Pengetahuan, sosial ekonomi, pola makan, pola haid, status gizi dan aktivitas fisik dengan kejadian anemia pada remaja putri", Jurnal Kebidanan dan Keperawatan Aisyiyah, 2018 
8 repository.up.ac.za

9 Barry A. Mizock. "The Multiple Organ Dysfunction Syndrome", Disease-a-Month, 2009 Publication

10 library.iugaza.edu.ps Internet Source

11 www.medicinecoupon.in

Exclude quotes

On

Exclude bibliography

On
Exclude matches

Off 


\section{Total cholesterol and C-reactive Protein (CRP) levels as prognostic markers for urosepsis}

GRADEMARK REPORT

FINAL GRADE

$/ 100$

PAGE 1

PAGE 2

PAGE 3

PAGE 4

PAGE 5

PAGE 6
GENERAL COMMENTS

Instructor 